\title{
Cyclic GMP-AMP Synthase
}

National Cancer Institute

\section{Source}

National Cancer Institute. Cyclic GMP-AMP Synthase. NCI Thesaurus. Code C106640.

Cyclic GMP-AMP synthase (522 aa, $\sim 59 \mathrm{kDa}$ ) is encoded by the human CGAS gene. This protein plays a role both cyclic dinucleotide synthesis and immune response activation. 